\title{
Serum and glucocorticoid regulated kinase and disturbed renal sodium transport in diabetes
}

\author{
Claire E Hills ${ }^{\mathbf{1}}$, Paul E Squires and Rosemary Bland \\ Department of Biological Sciences, Biomedical Research Institute, The University of Warwick, Coventry CV4 7AL, UK \\ ${ }^{1}$ Department of Infection, Immunity and Inflammation, Leicester Medical School, Maurice Shock Building, Leicester LE1 9HN, UK \\ (Correspondence should be addressed to R Bland; Email: rosemary.bland@warwick.ac.uk)
}

\begin{abstract}
Diabetes is associated with a number of side effects including retinopathy, neuropathy, nephropathy and hypertension. Recent evidence has shown that serum and glucocorticoid regulated kinase-1 (SGK1) is increased in models of diabetic nephropathy. While clearly identified as glucocorticoid responsive, SGK1 has also been shown to be acutely regulated by a variety of other factors. These include insulin, hypertonicity, glucose, increased intracellular calcium and transforming growth factor- $\beta$, all of which have been shown to be increased in type II diabetes. The principal role of SGK1 is to mediate sodium reabsorption via its actions on the
\end{abstract}

epithelial sodium channel (now known as sodium channel, nonvoltage-gated 1). Small alterations in the sodium resorptive capacity of the renal epithelia may have dramatic consequences for fluid volume regulation, and SGK1 maybe responsible for the development of hypertension associated with diabetes. This short commentary considers the evidence that supports the involvement of SGK1 in diabetic hypertension, but also discusses how aberrant sodium reabsorption may account for the cellular changes seen in the nephron.

Journal of Endocrinology (2008) 199, 343-349

\section{Introduction}

Diabetic nephropathy is a leading cause of chronic kidney disease and end-stage renal disease in the US and Europe (reviewed in Ritz 1999). This condition includes both structural and functional alterations in the kidney of the diabetic patient (Reeves \& Andreoli 2000). Structural changes include renal hypertrophy, thickening of the glomerular basement membrane and increased extracellular matrix accumulation in the glomeruli, while functional disturbances include increased glomerular filtration rate, glomerular hypertension, proteinuria, systemic hypertension and finally renal failure. Increases in the $\mathrm{Na}^{+}$resorptive capacity of the renal epithelia probably contributes to the pathogenesis of hypertension associated with diabetes. However, small alterations in $\mathrm{Na}^{+}$absorption by renal cells may be responsible for some of the changes seen in cellular function in diabetic nephropathy. One of the key regulators of $\mathrm{Na}^{+}$ reabsorption in the nephron is the serum and glucocorticoid regulated kinase-1 (SGK1). This short commentary looks at SGK1 pathophysiology and discusses the consequences of disturbed SGK1-mediated $\mathrm{Na}^{+}$reabsorption in diabetes in relation to the development of diabetic nephropathy.

\section{SGK1}

The serum and glucocorticoid kinase was originally isolated as a glucocorticoid responsive gene from rat mammary tumour cells and was termed $S g k 1$ to reflect its transcriptional regulation by both serum and glucocorticoids (Webster et al. 1993). Following its initial cloning, two additional closely related isoforms (SGK2 and SGK3) have been identified (Kobayashi et al. 1999). Sgk1 is expressed in a variety of tissues including kidney, eye, liver, ovary, heart, pancreas, skeletal muscle, intestine, and lung and brain (reviewed in Loffing et al. 2006). In the kidney, Sgk1 is predominantly expressed in the thick ascending limb of the loop of Henle, distal convoluted tubules and the cortical collecting duct (Alvarez de la Rosa et al. 2003). The subcellular localisation of Sgk1 is less clear. It has been found in the cytosol (Loffing et al. 2001, Hills et al. 2006a), associated with the $\mathrm{Na}^{+}, \mathrm{K}^{+}$-ATPase in the basolateral membrane (Alvarez de la Rosa et al. 2003) and co-localised with mitochondria (Cordas et al. 2007). Furthermore, treatment with serum or glucose causes translocation to the nucleus (Buse et al. 1999, Hills et al. 2006a). In the kidney, Sgk1 is a transcriptional target of aldosterone and functions as an important regulator of 
transepithelial sodium transport in the principal cells of the cortical collecting duct through its actions on the apical epithelial sodium channel (ENaC; now known as sodium channel, nonvoltage-gated 1 (SCNN1); reviewed by Pearce 2003, McCormick et al. 2005) and the $\mathrm{Na}^{+}, \mathrm{K}^{+}$-ATPase (Henke et al. 2002, Setiawan et al. 2002, Zecevic et al. 2004, Alvarez de la Rosa et al. 2006). However, in addition to regulating $\mathrm{ENaC}$ activity, SGK1 is involved in controlling a wide variety of cellular processes including apoptosis, ion transport and cellular differentiation (reviewed in Lang et al. 2006). SGK1 expression is regulated through gene transcription and regulated protein degradation, while kinase activity is dependent on phosphatidylinositol 3-kinase (PIK3) activity and subcellular localisation (reviewed in Lang et al. 2006). These various mechanisms allow SGK1 activity to adapt to different roles within the cell, dependent on the nature of the stimuli present (Firestone et al. 2003). In addition, three SGK1 splice variants have been identified recently and it is possible that these confer cellular functions (Simon et al. 2007).

\section{SGK1 and $\mathrm{ENaC}$ in the development of hypertension}

Sodium reabsorption occurs throughout the nephron by a number of apical transporters. Keys in this process are the thiazide-sensitive $\mathrm{Na}-\mathrm{Cl}$ cotransporter and the amiloridesensitive ENaC (Capasso et al. 2005). Expressed throughout the aldosterone-sensitive distal nephron (Loffing et al. 2001) and in the apical membrane of the principal cells in the cortical collecting duct (Hager et al. 2001), ENaCs promote $\mathrm{Na}^{+}$reabsorption from the glomerular filtrate. The driving force for this $\mathrm{Na}^{+}$reabsorption is maintained by the basolateral $\mathrm{Na}^{+}, \mathrm{K}^{+}$-ATPase (Vinciguerra et al. 2004).

The $\mathrm{ENaC}$ is a member of the $\mathrm{ENaC} /$ degenerin gene family (Kellenberger \& Schild 2002). Five ENaC subunits have been cloned namely $\alpha_{-}, \beta_{-}, \gamma_{-}, \delta_{-}$and $\varepsilon \mathrm{ENaC}$ (Ji et al. 2006). Although it appears that not all subunits are necessary to form a functional channel (Bonny et al. 1999), studies suggest that the $\alpha-, \beta$ - and $\gamma$-subunits are required. Proposed stoichiometries include either $2 \alpha / 1 \beta / 1 \gamma$ or alternatively $3 \alpha / 3 \beta / 3 \gamma$ (Kosari et al. 1998, Snyder et al. 1998). Recent studies have highlighted additional potential interactions with the $\delta$-subunit (Ji et al. 2006) and suggest that $\mathrm{ENaC}$ is a trimeric channel (Jasti et al. 2007).

The development of some forms of hypertension is clearly linked to increased $\mathrm{ENaC}$-mediated $\mathrm{Na}^{+}$reabsorption (reviewed in Pratt 2005). Activating mutations in the $\beta$ - and $\gamma$-subunits of $\mathrm{ENaC}$ are responsible for Liddle's syndrome, a severe form of low-renin and low-aldosterone hypertension (Liddle et al. 1963, Shimkets et al. 1994, Hansson et al. 1995). Likewise, amiloride and spironolactone (ENaC and mineralocorticoid receptor antagonists) are effective in reducing blood pressure (Saha et al. 2005). However, the effect of SGK1 on salt wasting and blood pressure are not as severe as seen in either mineralocorticoid or ENaC mutants (Hummler et al. 1996, Berger et al. 1998), although it is interesting to note that inactivation of $\alpha \mathrm{ENaC}$ in the cortical collecting duct alone does not alter or impair sodium balance (Rubera et al. 2003). In the salt-sensitive Dahl rat (a model of salt-sensitive hypertension), SGK1 expression is increased (Farjah et al. 2003). Likewise, genetic variants of the $S g k 1$ gene correlate with slightly increased blood pressure (Busjahn et al. 2002, von Wowern et al. 2005). However, the picture in mice lacking SGK1 is less clear and studies indicate that SGK1 is not solely responsible for the ENaC-mediated changes in blood pressure (reviewed in Lang et al. 2006). Lack of SGK1 has little effect on salt or fluid retention under normal dietary conditions, but under low-salt diets the $\mathrm{SGK} 1^{-1-}$ mice are unable to adequately retain $\mathrm{Na}^{+}$and so fail to maintain their blood pressure (Wulff et al. 2002). Likewise, a high-salt diet in SGK1 ${ }^{-1-}$ mice did not increase blood pressure (Huang et al. 2006a,b, while in mice fed deoxycorticosterone acetate (DOAC) on a high-salt diet, blood pressure significantly increased in both wild-type and SGK1-knockout animals (Artunc et al. 2006, Vallon et al. 2006). Interestingly, after 7 weeks of treatment, the SGK1 ${ }^{-1-}$ mice failed to show any further increase in blood pressure and did not develop renal scarring suggesting that a lack of SGK1 was protective against a DOAC/high-salt diet (Artunc et al. 2006). SGK3-knockout mice also display a mild phenotype with normal sodium handling and glucose tolerance (McCormick et al. 2004). It appears that SGK1 and SGK3 are not replacing each other, as double knockout mice (SGK1 and SGK3) do not have significantly different phenotypes from the single isoform knockouts (Grahammer et al. 2006).

SGK1 has been shown to increase ENaC-mediated $\mathrm{Na}^{+}$ transport by a number of mechanisms including increased apical membrane localisation of the $\mathrm{ENaC}$, inhibition of $\mathrm{ENaC}$ degradation (Debonneville et al. 2001) and stimulation of ENaC transcription (Boyd \& Naray-Fejes-Toth 2005). Studies examining the mechanism of SGK1-mediated modification of $\mathrm{ENaC}$ function have implicated the neural precursor cell expressed, developmentally downregulated gene 4 isoform (NEDD4-2) as a negative regulator of ENaC cell surface expression (Kamynina \& Staub 2002). NEDD4-2 is an ubiquitin ligase that directs proteasome mediated degradation of $\mathrm{ENaCs}$ (Malik et al. 2005). Activation of SGK1 via PIK3 leads to sequential phosphorylation of SGK1 at the Ser422 and Thr256 residues via the two downstream 3-phosphoinositide-dependent kinases PDPK2 and PDPK1 respectively (Kobayashi \& Cohen 1999, Park et al. 1999). Following activation by aldosterone, SGK1 binds to and phosphorylates NEDD4-2, impairing formation of the ENaC-NEDD4-2 complex and promoting $\mathrm{Na}^{+}$transport (Debonneville et al. 2001, Flores et al. 2005). Interestingly, phosphorylation of NEDD4-2 induces ubiquitination and degradation of SGK1 suggesting that SGK1 and NEDD4-2 are able to regulate each other (Zhou \& Snyder 2005). Thus, it has been suggested that in the absence of SGK1, the physical association between NEDD4-2 and $\mathrm{ENaC}$ results in 
ubiquitination of $\mathrm{ENaC}$ subunits inducing channel retrieval from the plasma membrane and subsequent proteasomal degradation (reviewed by Staub \& Verrey 2005). However, studies have indicated that SGK1-NEDD4-2 interaction and NEDD4-2 phosphorylation are not the sole regulators of $\mathrm{ENaC}$ function, with aldosterone increasing SGK1-mediated NEDD4-2 phosphorylation, albeit to a lesser extent than SGK1 phosphorylation (Flores et al. 2005). NEDD4-2 protein expression is also reduced by aldosterone and a lowsalt diet (Loffing-Cueni et al. 2006). Additionally, studies in Xenopus oocytes have shown direct regulation of $\mathrm{ENaC}$ open probability by NEDD4-2 (Michlig et al. 2005). Likewise, it appears that SGK1 can stimulate $\mathrm{ENaC}$ activity independent of NEDD4-2 interaction (Diakov \& Korbmacher 2004).

\section{SGK1 in cell volume regulation}

Renal epithelial cells are exposed to constant fluctuations in filtrate flow and osmolality. Consequently, tubule cells have developed a number of mechanisms to compensate for alterations in filtrate flow rates and to regulate osmotically induced changes in cell volume. However, the mechanisms by which renal epithelial cells detect and subsequently respond to flow and osmotic changes require further clarification. Two potential complementary regulatory mechanisms include SGK1 and the mechano-sensitive transient receptor potential channel (TRPV4), a $\mathrm{Ca}^{2+}$ permeable action channel that is proposed to respond to numerous stimuli including increased flow rates and cell swelling (Cohen 2005, Wu et al. 2007). In addition to its identification as a glucocorticoid responsive gene, Sgk1 was also cloned from human liver cells, as one of the principal volume-regulated protein kinases that serve to restore cell volume upon exposure to hypertonicity (Waldegger et al. 1997). Often referred to as $h S g k$ in the literature, it is virtually identical to SGK1 and in mammals its expression is markedly increased following hypertonic cell shrinkage, an effect mediated via the p38 mitogen-activated protein kinase (MAPK; Bell et al. 2000, Waldegger et al. 2000). However, in A6 cells, which are derived from the freshwater African claw-toed frog, SGK1 is stimulated by hypotonicity (Rozansky et al. 2002). The reason behind this difference is not yet apparent. However, it is interesting to note that in A6 cells hypotonicity results in increased intracellular calcium concentration (Rozansky et al. 2002, Taruno et al. 2008), which we have shown in human renal cells causes increased SGK1 expression (Hills et al. 2006a).

\section{SGK1 in diabetic nephropathy}

Poorly controlled type II diabetes results in hyperinsulinaemia and hyperglycaemia, which are thought to be the predominant factors involved in the development of diabetic nephropathy. Studies have shown that SGK1 is increased in models of diabetic nephropathy where insulin and glucose have been shown to stimulate SGK1 expression and phosphorylation via PIK3 (Kumar et al. 1999, Lang et al. 2000, Perrotti et al. 2001, Wang et al. 2005) and SGK1 polymorphisms are associated with type II diabetes (Schwab et al. 2008). Furthermore, signalling molecules located upstream of SGK1 including transforming growth factor- $\beta$ (TGF $\beta 1)$, protein kinase $\mathrm{C}$ (PKC), diacylglycerol and $\mathrm{Ca}^{2+}$ all show increased expression in models of type II diabetes. Likewise, ENaC expression is induced by infusion of insulin in streptozotocin-induced diabetes (Song et al. 2003, 2006), while mineralocorticoid receptor antagonists have been shown to reduce renal injury in models of type I and type II diabetes mellitus (Guo et al. 2006). These changes clearly have the potential to induce the hypertension that is seen so often in diabetics. However, while we have considered hyperglycaemic evoked changes in SGK1 expression and the resultant effect that this may have over ENaC-mediated $\mathrm{Na}^{+}$ transport, it is vital that we also consider the direct effect of glucose on the collecting duct. Glycosuria, a consequence of hyperglycaemia, results in an osmotic diuresis leading to high urine flow rates and fluctuations in urine osmolality. These changes in urine composition and flow characteristics are able to modify SGK1-mediated $\mathrm{Na}^{+}$reabsorption either directly or indirectly via changes in cell volume.

Hyperosmotic urine will facilitate osmotically induced cell shrinkage in the renal epithelial cells. This in turn will activate SGK1 (Bell et al. 2000) increasing both ENaC-mediated $\mathrm{Na}^{+}$ and water uptake thereby inducing a regulatory cell volume increase. However, SGK1 has been shown to alter expression and insertion of the glucose transporters (GLUT1) and sodium glucose co-transporter type 1 (SGLT1) into the cell membrane (Dieter et al. 2004, Palmada et al. 2006). As a result, glucose is able to enter the hexosamine or the polyol pathway. In the polyol pathway, glucose, in the presence of aldose reductase, is reduced to sorbitol, an organic osmolyte, which increases intracellular osmolarity leading to cell swelling (Schüttert et al. 2002). This would instigate a regulatory cell volume decrease, mediated most likely by increased TRPV4 activity and a concomitant reduction in SGK1 activity. Evidence suggests that urinary sorbitol excretion is increased in diabetic rats, indicating increased conversion of glucose to sorbitol. Administration of the aldose reductase inhibitor, epalrestat, reduced both total body and urinary sorbitol levels (Tsugawa et al. 2004).

Increased urine flow rates may also regulate $\mathrm{ENaC}$ mediated $\mathrm{Na}^{+}$transport (Satlin et al. 2001, Morimoto et al. 2006) through direct modulation of the $\mathrm{ENaC}$ or indirect effects on cell signalling. Numerous studies have reported elevated levels of cytosolic calcium in patients with diabetes (reviewed in Symonian et al. 1998), an effect linked to hyperglycaemia in both proximal and distal tubule cells of the kidney (Symonian et al. 1998, Hills et al. 2006a). Cell swelling in the proximal tubule is also associated with increased $\left[\mathrm{Ca}^{2+}\right]_{\mathrm{i}}$ and this is linked to activation of phospholipase $\mathrm{C}$, the generation of inositol trisphosphate and activation of PKC (O'Neil \& Leng 1997). We have demonstrated that cells in the human collecting duct (HCD cells) are sensitive to touch 
(a surrogate for cell membrane stretch and cell volume expansion) and that this is associated with a TRPV4 mediated rise in $\left[\mathrm{Ca}^{2+}\right]_{\mathrm{i}}$ (Hills et al. 2006b). In HCD cells, this increase in $\left[\mathrm{Ca}^{2+}\right]_{\mathrm{i}}$ rapidly propagates to adjacent cells via the gap junction protein connexin-43 and it is this $\mathrm{Ca}^{2+}$-induced signal that is thought to aid cell volume recovery through activation of $\mathrm{K}^{+}$and $\mathrm{Cl}^{-}$channels subsequently restoring cell volume. However, constitutive activation of TRPV4 under pathological conditions, in those cells exposed to an increased flow rate, may result in a constant state of cell shrinkage and high $\left[\mathrm{Ca}^{2+}\right]_{\mathrm{i}}$ levels. In an attempt to respond and counteract the effects of TRPV4, SGK1 expression will be induced, a response stimulated further by the increased $\left[\mathrm{Ca}^{2+}\right]_{\mathrm{i}}$ levels generated in response to TRPV4 activation. While there to aid the cell volume recovery process, a rise in $\left[\mathrm{Ca}^{2+}\right]_{\mathrm{i}}$ will induce both SGK1 and $\alpha \mathrm{ENaC}$ expression thus further exacerbating the state of aberrant renal $\mathrm{Na}^{+}$handling.
It is also interesting to consider the role of SGK1 in fibrosis, as deposition of extracellular matrix is a hallmark of diabetic nephropathy (Mason \& Wahab 2003). TGF $\beta 1$ is thought to be key in this process (reviewed in Reeves \& Andreoli 2000) and is increased by glucose in renal cells (Di Paolo et al. 1996, Hoffman et al. 1998, Hills et al. 2006a). Whilst the downstream targets of TGF $\beta 1$ mediating the underlying pathophysiology of diabetic nephropathy remain largely elusive, cell hypertrophy and increased intracellular $\mathrm{Na}^{+}$ observed in response to elevated TGF $\beta 1$ levels may in part be mediated by increased SGK1 activity. SGK1 is upregulated by TGF $\beta 1$ in a number of cell types (Waldegger et al. 1999, Lang et al. 2000, Hills et al. 2006a). In addition, glucose-induced changes in SGK1 mediate fibronectin formation in diabetic mice (Feng et al. 2005). It is interesting to consider the crosstalk between the TGF $\beta 1$ and MAPK signalling pathway highlighting utilisation of the same signalling pathway as that

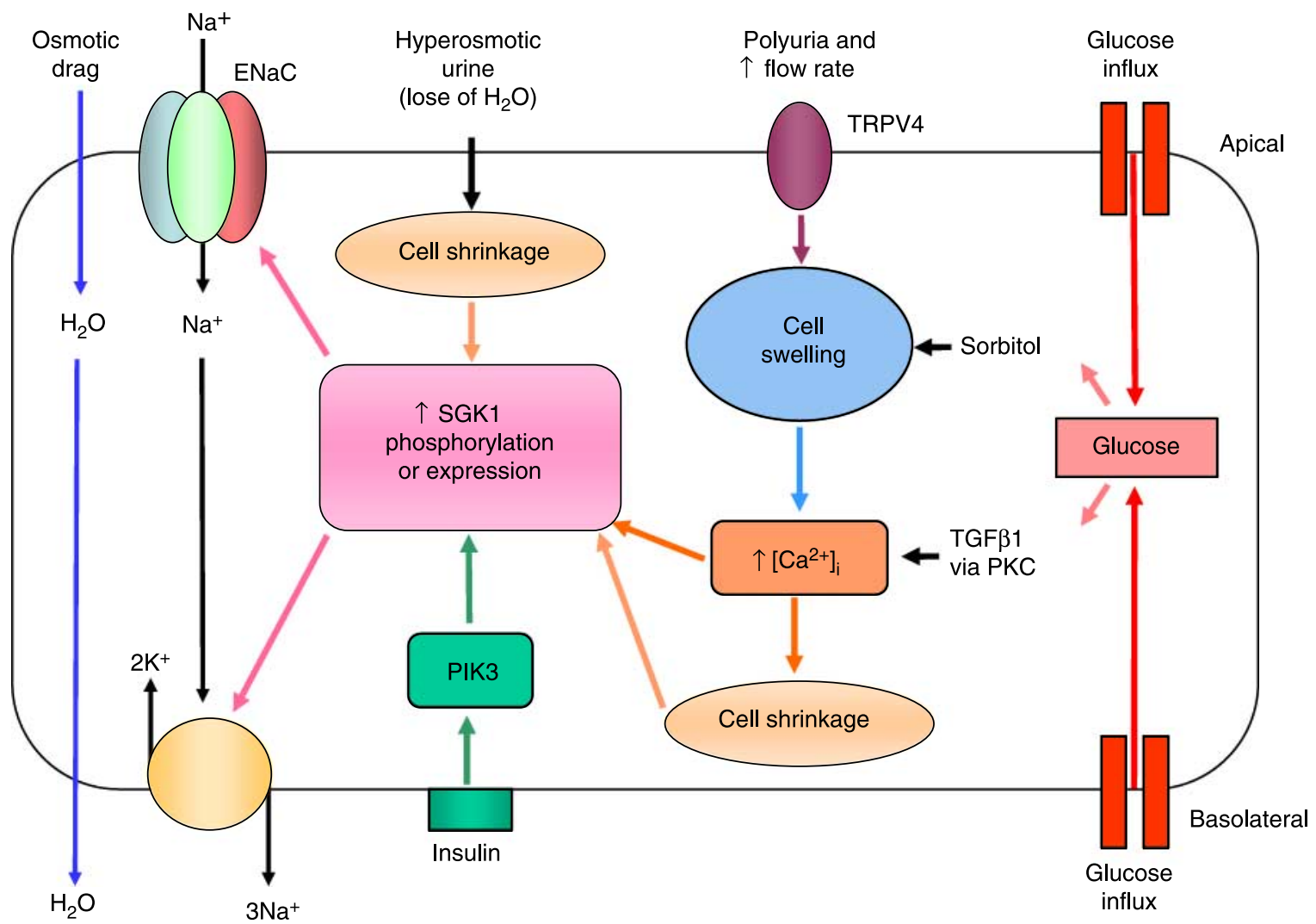

Figure 1 Model for the regulation of SGK1-dependent $\mathrm{Na}^{+}$transport in type II diabetes. Phosphorylated SGK1 allows for insertion and retention of ENaCs into the apical cell membrane, promoting $\mathrm{ENaC}$-mediated $\mathrm{Na}^{+}$reabsorption from the lumen of the cortical collecting duct. SGK1 also stimulates the $\mathrm{Na}^{+}, \mathrm{K}^{+}$-ATPase. TRPV4 receptors may be activated either by the high urine flow rates that are associated with polyuria or as a result of osmotically induced cell swelling. This will be compensated for by a regulatory cell volume decrease leading to cell shrinkage. Similarly glycosuria may initiate cell shrinkage as water is lost to the lumen. Cell shrinkage is a key trigger for SGK1 activation. Insulin and glucose are also able to modify SGK1 activity. Insulin induces SGK1 phosphorylation via PIK3, while glucose increases SGK1 expression via TGF $\beta 1$ and PKC. We suggest that all aspects of type II diabetes promote an increase in $\mathrm{ENaC}$-mediated $\mathrm{Na}^{+}$reabsorption. This will result in increased $\mathrm{Na}^{+}$and water retention, an imbalance that may predispose the development of hypertension that is associated with diabetes. Furthermore, these changes may contribute towards the loss of cell function and nephron damage that is associated with diabetic nephropathy. Full colour version of this figure available via http://dx.doi.org/10.1677/JOE-08-0295. 
initiated in response to osmotic stress. TGF $\beta 1$ formation together with osmotically driven increases in SGK1 provides a link between poorly controlled plasma glucose and the development of excess $\mathrm{ENaC}$-mediated $\mathrm{Na}^{+}$resorption that underlies secondary hypertension and nephron damage seen in people with diabetes.

\section{Concluding comments}

Recent studies have demonstrated that diabetes is associated with enhanced SGK1 expression and/or function and it is likely that changes in SGK1-mediated sodium transport are responsible for the development of diabetic hypertension. However, subtle changes in sodium transport will also instigate a number of downstream signals that can influence both cell volume and integrity, which may result in the loss of nephron function seen in diabetic nephropathy. In physiological conditions, the $\mathrm{ENaC}$, the $\mathrm{Na}^{+}, \mathrm{K}^{+}$-ATPase, TRPV4 and SGK1 are likely to work together to maintain a constant intracellular $\left[\mathrm{Na}^{+}\right]$and so cell volume. However, in diabetes, the epithelial cells of the distal nephron are exposed to a number of stimuli capable of increasing SGK1mediated $\mathrm{Na}^{+}$transport (Fig. 1). Hyperinsulinaemia and hyperglycaemia will both induce SGK1 signalling. Glycosuria causes an osmotic diuresis, which may lead to osmotic cell shrinkage, activation of TRPV4 and a consequent increase in SGK1 activity. Of particular interest though is the demonstration of GLUT1, SGLT1 (Suzuki et al. 1996) and GLUT12 (Linden et al. 2006) on the apical membrane of distal tubules and the collecting duct. It is usually assumed that these cells would not normally be exposed to glucose on this surface, but this is clearly not the case in diabetes. Apical expression of SGLT1 and GLUT12 suggests that glucose may have direct effects both at the basolateral and apical surface, but few in vitro studies have attempted to delineate between the cell surface responding. Therefore, in diabetes, continuous exposure to increased high glucose may see constitutive activation of SGK1 signalling leading to excessive $\mathrm{Na}^{+}$ reabsorption further exacerbating both the hypertension and the cellular damage seen in diabetes (Fig. 1).

\section{Declaration of interest}

There is no conflict of interest that could be perceived as prejudicing the impartiality of the research reported.

\section{Funding}

R B and P E S are supported by funding from The Diabetes, Endocrine and Immersion Research Trust and Diabetes UK.

\section{Acknowledgements}

C E H was a BBSRC PhD Student (R B and P E S).

\section{References}

Alvarez de la Rosa D, Coric T, Todorovic N, Shao D, Wang T \& Canessa CM 2003 Distribution and regulation of expression of serum- and glucocorticoid-induced kinase-1 in the rat kidney. Journal of Physiology 551 455-466.

Alvarez de la Rosa D, Gimenez I, Forbush B \& Canessa CM 2006 SGK1 activates $\mathrm{Na}^{+}-\mathrm{K}^{+}$-ATPase in amphibian renal epithelial cells. American Journal of Physiology. Cell Physiology 290 C492-C498.

Artunc F, Amann K, Nasir O, Friedrich B, Sandulache D, Jahovic N, Risler T, Vallon V, Wulff P, Kuhl D et al. 2006 Blunted DOCA/high salt induced albuminuria and renal tubulointerstitial damage in gene-targeted mice lacking SGK1. Journal of Molecular Medicine 84 737-746.

Bell LM, Leong ML, Kim B, Wang E, Park J, Hemmings BA \& Firestone GL 2000 Hyperosmotic stress stimulates promoter activity and regulates cellular utilization of the serum- and glucocorticoid-inducible protein kinase (Sgk) by a p38 MAPK-dependent pathway. Journal of Biological Chemistry 275 25262-25272.

Berger S, Bleich M, Schmid W, Cole TJ, Peters J, Watanabe H, Kriz W, Warth R, Greger R \& Schutz G 1998 Mineralocorticoid receptor knockout mice: pathophysiology of $\mathrm{Na}^{+}$metabolism. PNAS 95 9424-9429.

Bonny O, Chraibi A, Loffing J, Jaeger NF, Gründer S, Horisberger JD \& Rossier BC 1999 Functional expression of a pseudohypoaldosteronism type 1 mutated epithelial $\mathrm{Na}^{+}$channel lacking the pore-forming region of its alpha subunit. Journal of Clinical Investigation 104 849-850.

Boyd C \& Naray-Fejes-Toth A 2005 Gene regulation of ENaC subunits by serum- and glucocorticoid-inducible kinase-1. American Journal of Physiology. Renal Physiology 288 505-512.

Buse P, Tran SH, Luther E, Phu PT, Aponte GW \& Firestone GL 1999 Cell cycle and hormonal control of nuclear-cytoplasmic localization of the serum- and glucocorticoid-inducible protein kinase, Sgk, in mammary tumor cells. A novel convergence point of anti-proliferative and proliferative cell signaling pathways. Journal of Biological Chemistry 274 7253-7263.

Busjahn A, Aydin A, Uhlmann R, Krasko C, Bähring S, Szelestei T, Feng Y, Dahm S, Sharma AM, Luft FC et al. 2002 Serum- and glucocorticoidregulated kinase (SGK1) gene and blood pressure. Hypertension 40 256-260.

Capasso G, Cantone A, Evangelista C, Zacchia M, Trepiccione F, Acone D \& Rizzo M 2005 Channels, carriers, and pumps in the pathogenesis of sodium-sensitive hypertension. Seminars in Nephrology 25 419-424.

Cohen DM 2005 TRPV4 and the mammalian kidney. Pflugers Archiv 451 $168-175$.

Cordas E, Náray-Fejes-Tóth A \& Fejes-Tóth G 2007 Subcellular location of serum- and glucocorticoid-induced kinase- 1 in renal and mammary epithelial cells. American Journal of Physiology. Cell Physiology 292 C1971-C1981.

Debonneville C, Flores SY, Kamynina E, Plant PJ, Tauxe C, Thomas MA, Munster C, Chraibi A, Pratt JH, Horisberger JD et al. 2001 Phosphorylation of Nedd4-2 by Sgk1 regulates epithelial $\mathrm{Na}\left({ }^{+}\right)$channel cell surface expression. EMBO Journal 20 7052-7059.

Diakov A \& Korbmacher C 2004 A novel pathway of epithelial sodium channel activation involves a serum- and glucocorticoid-inducible kinase consensus motif in the C terminus of the channel's alpha-subunit. Journal of Biological Chemistry 279 38134-38142.

Dieter M, Palmada M, Rajamanickam J, Aydin A, Busjahn A, Boehmer C, Luft FC \& Lang F 2004 Regulation of glucose transporter SGLT1 by ubiquitin ligase Nedd4-2 and kinases SGK1, SGK3, and PKB. Obesity Research 12 862-870.

Farjah M, Roxas BP, Geenen DL \& Danziger RS 2003 Dietary salt regulates renal SGK1 abundance: relevance to salt sensitivity in the Dahl rat. Hypertension 41 874-878.

Feng Y, Wang Q, Wang Y, Yard B \& Lang F 2005 SGK1-mediated fibronectin formation in diabetic nephropathy. Cellular Physiology and Biochemistry 16 237-244.

Firestone GL, Giampaolo JR \& O'Keeffe BA 2003 Stimulus-dependent regulation of serum and glucocorticoid inducible protein kinase (SGK) transcription, subcellular localization and enzymatic activity. Cellular Physiology and Biochemistry 13 1-12. 
Flores SY, Loffing-Cueni D, Kamynina E, Daidie D, Gerbex C, Chabanel S, Dudler J, Loffing J \& Staub O 2005 Aldosterone-induced serum and glucocorticoid-induced kinase 1 expression is accompanied by Nedd4-2 phosphorylation and increased $\mathrm{Na}^{+}$transport in cortical collecting duct cells. Journal of the American Society of Nephrology 16 2279-2287.

Grahammer F, Artunc F, Sandulache D, Rexhepaj R, Friedrich B, Risler T, McCormick JA, Dawson K, Wang J, Pearce D et al. 2006 Renal function of gene-targeted mice lacking both SGK1 and SGK3. American Journal of Physiology. Regulatory, Integrative and Comparative Physiology 290 R945-R 950.

Guo C, Martinez-Vasquez D, Mendez GP, Toniolo MF, Yao TM, Oestreicher EM, Kikuchi T, Lapointe N, Pojoga L, Williams GH et al. 2006 Mineralocorticoid receptor antagonist reduces renal injury in rodent models of types 1 and 2 diabetes mellitus. Endocrinology 147 5363-5373.

Hager H, Kwon TH, Vinnikova AK, Masilamani S, Brooks HL, Frøkiaer J, Knepper MA \& Nielsen S 2001 Immunocytochemical and immunoelectron microscopic localization of alpha-, beta-, and gamma-ENaC in rat kidney. American Journal of Physiology. Renal Physiology 280 F1093-F1106.

Hansson JH, Nelson-Williams C, Suzuki H, Schild L, Shimkets R, Lu Y, Canessa C, Iwasaki T, Rossier B \& Lifton RP 1995 Hypertension caused by a truncated epithelial sodium channel gamma subunit: genetic heterogeneity of Liddle syndrome. Nature Genetics 11 76-82.

Henke G, Setiawan I, Böhmer C \& Lang F 2002 Activation of $\mathrm{Na}^{+} / \mathrm{K}^{+}$ATPase by the serum and glucocorticoid-dependent kinase isoforms. Kidney and Blood Pressure Research 25 370-374.

Hills CE, Bland R, Bennett J, Ronco PM \& Squires PE 2006a High glucose up-regulates ENaC and SGK1 expression in HCD-cells. Cellular Physiolog and Biochemistry 18 337-346.

Hills CE, Bland R, Wheelans DC, Bennett J, Ronco PM \& Squires PE $2006 b$ Glucose-evoked alterations in connexin 43-mediated cell-to-cell communication in human collecting duct: a possible role in diabetic nephropathy. American Journal of Physiology. Renal Physiology 291 F1045-F1051.

Hoffman BB, Sharma K, Zhu Y \& Ziyadeh FN 1998 Transcriptional activation of transforming growth factor-beta1 in mesangial cell culture by high glucose concentration. Kidney International 54 1107-1116.

Huang DY, Boini KM, Friedrich B, Metzger M, Just L, Osswald H, Wulff P, Kuhl D, Vallon V \& Lang F 2006a Blunted hypertensive effect of combined fructose and high-salt diet in gene-targeted mice lacking functional serumand glucocorticoid-inducible kinase SGK1. American Journal of Physiology. Regulatory, Integrative and Comparative Physiology 290 R935-R944.

Huang DY, Boini KM, Osswald H, Friedrich B, Artunc F, Ullrich S, Rajamanickam J, Palmada M, Wulff P, Kuhl D et al. $2006 b$ Resistance of mice lacking the serum- and glucocorticoid-inducible kinase SGK1 against salt-sensitive hypertension induced by a high-fat diet. American Journal of Physiology. Renal Physiology 291 F1264-F1273.

Hummler E, Barker P, Gatzy J, Beermann F, Verdumo C, Schmidt A, Boucher R \& Rossier BC 1996 Early death due to defective neonatal lung liquid clearance in alpha-ENaC-deficient mice. Nature Genetics 12 325-328.

Jasti J, Furukawa H, Gonzales EB \& Gouaux E 2007 Structure of acid-sensing ion channel 1 at 1.9 A resolution and low pH. Nature 449 316-323.

Ji HL, Su XF, Kedar S, Li J, Barbry P, Smith PR, Matalon S \& Benos DJ 2006 Delta-subunit confers novel biophysical features to alpha beta gammahuman epithelial sodium channel $(\mathrm{ENaC})$ via a physical interaction. Journal of Biological Chemistry 281 8233-8241.

Kamynina E \& Staub O 2002 Concerted action of ENaC, Nedd4-2, and Sgk1 in transepithelial $\mathrm{Na}^{+}{ }^{+}$) transport. American Journal of Physiology. Renal Physiology 283 F377-F387.

Kellenberger S \& Schild L 2002 Epithelial sodium channel/degenerin family of ion channels: a variety of functions for a shared structure. Physiological Reviews 82 735-767.

Kobayashi T \& Cohen P 1999 Activation of serum- and glucocorticoidregulated protein kinase by agonists that activate phosphatidylinositide 3-kinase is mediated by 3-phosphoinositide-dependent protein kinase-1 (PDK1) and PDK2. Biochemical Journal 339 319-328.

Kobayashi T, Deak M, Morrice N \& Cohen P 1999 Characterization of the structure and regulation of two novel isoforms of serum- and glucocorticoid-induced protein kinase. Biochemical Journal 344 189-197.
Kosari F, Sheng S, Li J, Mak DO, Foskett JK \& Kleyman TR 1998 Subunit stoichiometry of the epithelial sodium channel. Journal of Biological Chemistry 273 13469-13474.

Kumar JM, Brooks DP, Olson BA \& Laping NJ 1999 Sgk, a putative serine/threonine kinase, is differentially expressed in the kidney of diabetic mice and humans. Journal of the American Society of Nephrology 10 2488-2494.

Lang F, Klingel K, Wagner CA, Stegen C, Warntges S, Friedrich B, Lanzendorfer M, Melzig J, Moschen I, Steuer S et al. 2000 Deranged transcriptional regulation of cell-volume-sensitive kinase hSGK in diabetic nephropathy. PNAS 97 8157-8162.

Lang F, Bohmer C, Palmada M, Seebohm G, Strutz-Seebohm N \& Vallon V 2006 (Patho)physiological significance of the serum- and glucocorticoidinducible kinase isoforms. Physiological Reviews 86 1151-1178.

Liddle GW, Bledsoe T \& Coppage WS Jr 1963 A familial renal disorder simulating primary aldosteronism but with negligible aldosterone secretion. Transactions of the Association of American Physicians 76 199-213.

Linden KC, DeHaan CL, Zhang Y, Glowacka S, Cox AJ, Kelly DJ \& Rogers S 2006 Renal expression and localization of the facilitative glucose transporters GLUT1 and GLUT12 in animal models of hypertension and diabetic nephropathy. American Journal of Physiology. Renal Physiology 290 F205-F213.

Loffing J, Zecevic M, Féraille E, Kaissling B, Asher C, Rossier BC, Firestone GL, Pearce D \& Verrey F 2001 Aldosterone induces rapid apical translocation of $\mathrm{ENaC}$ in early portion of renal collecting system: possible role of SGK. American Journal of Physiology. Renal Physiology 280 F675-F682.

Loffing J, Flores SY \& Staub O 2006 Sgk kinases and their role in epithelial transport. Annual Review of Physiology 68 461-490.

Loffing-Cueni D, Flores SY, Sauter D, Daidié D, Siegrist N, Meneton P, Staub O \& Loffing J 2006 Dietary sodium intake regulates the ubiquitin-protein ligase nedd4-2 in the renal collecting system. Journal of the American Society of Nephrology 17 1264-1274.

Malik B, Yue Q, Yue G, Chen XJ, Price SR, Mitch WE \& Eaton DC 2005 Role of Nedd4-2 and polyubiquitination in epithelial sodium channel degradation in untransfected renal A6 cells expressing endogenous ENaC subunits. American Journal of Physiology. Renal Physiology 289 F107-F116.

Mason RM \& Wahab A 2003 Extracellular matrix metabolism in diabetic nephropathy. Journal of the American Society of Nephrology 14 1358-1373.

McCormick JA, Feng Y, Dawson K, Behne MJ, Yu B, Wang J, Wyatt AW, Henke G, Grahammer F, Mauro TM et al. 2004 Targeted disruption of the protein kinase SGK3/CISK impairs postnatal hair follicle development. Molecular Biology of the Cell 15 4278-4288.

McCormick JA, Bhalla V, Pao AC \& Pearce D 2005 SGK1: a rapid aldosterone-induced regulator of renal sodium reabsorption. Physiology 20 134-139.

Michlig S, Harris M, Loffing J, Rossier BC \& Firsov D 2005 Progesterone down-regulates the open probability of the amiloride-sensitive epithelial sodium channel via a Nedd4-2-dependent mechanism. Journal of Biological Chemistry 280 38264-38270.

Morimoto T, Liu W, Woda C, Carattino MD, Wei Y, Hughey RP, Apodaca G, Satlin LM \& Kleyman TR 2006 Mechanism underlying flow stimulation of sodium absorption in the mammalian collecting duct. American Journal of Physiology. Renal Physiology 291 F663-F669.

O'Neil RG \& Leng L 1997 Osmo-mechanically sensitive phosphatidylinositol signaling regulates a $\mathrm{Ca}^{2+}$ influx channel in renal epithelial cells. American Journal of Physiology. Renal Physiology 273 F120-F128.

Palmada M, Boehmer C, Akel A, Rajamanickam J, Jeyaraj S, Keller K \& Lang F 2006 SGK1 kinase upregulates GLUT1 activity and plasma membrane expression. Diabetes $\mathbf{5 5}$ 421-427.

Di Paolo S, Gesualdo L, Ranieri E, Grandaliano G \& Schena FP 1996 High glucose concentration induces the overexpression of transforming growth factor-beta through the activation of a platelet-derived growth factor loop in human mesangial cells. American Journal of Physiology 149 2095-2106.

Park J, Leong ML, Buse P, Maiyar AC, Firestone GL \& Hemmings BA 1999 Serum and glucocorticoid-inducible kinase (SGK) is a target of the PI 3-kinase-stimulated signaling pathway. EMBO Journal 18 3024-3033.

Pearce D 2003 SGK1 regulation of epithelial sodium transport. Cellular Physiology and Biochemistry 13 13-20. 
Perrotti N, He RA, Phillips SA, Haft CR \& Taylor SI 2001 Activation of serum- and glucocorticoid-induced protein kinase (Sgk) by cyclic AMP and insulin. Journal of Biological Chemistry 276 9406-9412.

Pratt JH 2005 Central role for $\mathrm{ENaC}$ in development of hypertension. Journal of the American Society of Nephrology 16 3154-3159.

Reeves WB \& Andreoli TE 2000 Transforming growth factor beta contributes to progressive diabetic nephropathy. PNAS 97 7667-7669.

Ritz E 1999 Nephropathy in type II diabetes. Journal of Internal Medicine $\mathbf{2 4 5}$ $111-126$.

Rozansky DJ, Wang J, Doan N, Purdy T, Faulk T, Bhargava A, Dawson K \& Pearce D 2002 Hypotonic induction of SGK1 and $\mathrm{Na}^{+}$transport in A6 cells. American Journal of Physiology. Renal Physiology 283 F105-F113.

Rubera I, Loffing J, Palmer LG, Frindt G, Fowler-Jaeger N, Sauter D, Carroll T, McMahon A, Hummler E \& Rossier BC 2003 Collecting duct-specific gene inactivation of alphaENaC in the mouse kidney does not impair sodium and potassium balance. Journal of Clinical Investigation 112 554-565.

Saha C, Eckert GJ, Ambrosius WT, Chun TY, Wagner MA, Zhoa Q \& Pratt JH 2005 Improvement in blood pressure with inhibition of the epithelial sodium channel in blacks with hypertension. Hypertension 46 481-487.

Satlin LM, Sheng S, Woda CB \& Kleyman TR 2001 Epithelial Na ${ }^{+}$) channels are regulated by flow. American Journal of Physiology. Renal Physiology 280 F1010-F1018.

Schuttert JB, Fiedler GM, Grupp C, Blaschke S \& Grunewald RW 2002 Sorbitol transport in rat renal inner medullary interstitial cells. Kidney International 61 1407-1415.

Schwab M, Lupescu A, Mota M, Mota E, Frey A, Simon P, Mertens PR, Floege J, Luft F, Asante-Poku S et al. 2008 Association of SGK1 gene polymorphisms with type II diabetes. Cellular Physiology and Biochemistry 21 151-160.

Setiawan I, Henke G, Feng Y, Böhmer C, Vasilets LA, Schwarz W \& Lang F 2002 Stimulation of Xenopus oocyte $\mathrm{Na}(+), \mathrm{K}(+)$ ATPase by the serum and glucocorticoid-dependent kinase sgk1. Pflugers Archiv: European Journal of Physiology 444 426-431.

Shimkets RA, Warnock DG, Bositis CM, Nelson-Williams C, Hansson JH, Schambelan M, Gill JR Jr, Ulick S, Milora RV, Findling JW et al. 1994 Liddle's syndrome: heritable human hypertension caused by mutations in the beta subunit of the epithelial sodium channel. Cell 79 407-414.

Simon P, Schneck M, Hochstetter T, Koutsouki E, Mittelbronn M, Merseburger A, Weigert C, Niess A \& Lang F 2007 Differential regulation of serum- and glucocorticoid-inducible kinase 1 (SGK1) splice variants based on alternative initiation of transcription. Cellular Physiology and Biochemistry 20 715-728.

Snyder PM, Cheng C, Prince LS, Rogers JC \& Welsh MJ 1998 Electrophysiological and biochemical evidence that DEG/ENaC cation channels are composed of nine subunits. Journal of Biological Chemistry 273 681-684.

Song J, Knepper MA, Verbalis JG \& Ecelbarger CA 2003 Increased renal $\mathrm{ENaC}$ subunit and sodium transporter abundances in streptozotocininduced type I diabetes. American Journal of Physiology. Renal Physiology 285 F1125-F1137.

Song J, Hu X, Riazi S, Tiwari S, Wade JB \& Ecelbarger CA 2006 Regulation of blood pressure, the epithelial sodium channel $(\mathrm{ENaC})$, and other key renal sodium transporters by chronic insulin infusion in rats. American Journal of Physiology. Renal Physiology 290 F1055-F1064.

Staub O \& Verrey F 2005 Impact of Nedd4 proteins and serum and glucocorticoid-induced kinases on epithelial $\mathrm{Na}^{+}$transport in the distal nephron. Journal of the American Society of Nephrology 16 3167-3174.

Suzuki T, Fujikura K \& Takata K $1996 \mathrm{Na}\left({ }^{+}\right)$-dependent glucose transporter SGLT1 is localized in the apical plasma membrane upon completion of tight junction formation in MDCK cells. Histochemistry and Cell Biology 106 529-533.

Symonian M, Smogorzewski M, Marcinkowski W, Krol E \& Massry SG 1998 Mechanisms through which high glucose concentration raises $\left[\mathrm{Ca}^{2+}\right]_{\mathrm{i}}$ in renal proximal tubular cells. Kidney International 54 1206-1213.
Taruno A, Niisato N \& Marunaka Y 2008 Intracellular calcium plays a role as the second messenger of hypotonic stress in gene regulation of SGK1 and $\mathrm{ENaC}$ in renal epithelial A6 cells. American Journal of Physiology. Renal Physiology 294 F177-F186.

Tsugawa T, Shinohara R, Nagasaka A, Nakano I, Takeda F, Nagata M, Oda N, Sawai Y, Hayakawa N, Suzuki A et al. 2004 Alteration of urinary sorbitol excretion in WBN-kob diabetic rats - treatment with an aldose reductase inhibitor. Journal of Endocrinology 181 429-435.

Vallon V, Wyatt AW, Klingel K, Huang DY, Hussain A, Berchtold S, Friedrich B, Grahammer F, Belaiba RS, Görlach A et al. 2006 SGK1-dependent cardiac CTGF formation and fibrosis following DOCA treatment. Journal of Molecular Medicine 84 396-404.

Vinciguerra M, Arnaudeau S, Mordasini D, Rousselot M, Bens M, Vandewalle A, Martin PY, Hasler U \& Feraille E 2004 Extracellular hypotonicity increases $\mathrm{Na}, \mathrm{K}$-ATPase cell surface expression via enhanced $\mathrm{Na}^{+}$influx in cultured renal collecting duct cells. Journal of the American Society of Nephrology 15 2537-2547.

Waldegger S, Barth P, Raber G \& Lang F 1997 Cloning and characterization of a putative human serine/threonine protein kinase transcriptionally modified during anisotonic and isotonic alterations of cell volume. PNAS 94 4440-4445.

Waldegger S, Klingel K, Barth P, Sauter M, Rfer ML, Kandolf R \& Lang F 1999 h-sgk serine-threonine protein kinase gene as transcriptional target of transforming growth factor beta in human intestine. Gastroenterology 116 1081-1088.

Waldegger S, Gabrysch S, Barth P, Fillon S \& Lang F 2000 h-sgk serinethreonine protein kinase as transcriptional target of $\mathrm{p} 38$ /MAP kinase pathway in HepG2 human hepatoma cells. Cellular Physiology and Biochemistry 10 203-208.

Wang Q, Zhang X, Wang Y, Deng A, Zhu Z \& Feng Y 2005 Significance and expression of serum and glucocorticoid-inducible kinase in kidney of mice with diabetic nephropathy. Journal of Huazhong University of Science and Technology. Medical Sciences 25 170-173.

Webster MK, Goya L, GE Y, Maiyar AC \& Firestone GL 1993 Characterization of sgk, a novel member of the serine/threonine protein kinase gene family which is transcriptionally induced by glucocorticoids and serum. Molecular and Cellular Biology 13 2031-2040.

von Wowern F, Berglund G, Carlson J, Månsson H, Hedblad B \& Melander O 2005 Genetic variance of SGK-1 is associated with blood pressure, blood pressure change over time and strength of the insulin-diastolic blood pressure relationship. Kidney International 68 2164-2172.

Wu L, Gao X, Brown RC, Heller S \& O'Neil RG 2007 Dual role of the TRPV4 channel as a sensor of flow and osmolality in renal epithelial cells. American Journal of Physiology. Renal Physiology 293 F1699-F1713.

Wulff P, Vallon V, Huang DY, Völkl H, Yu F, Richter K, Jansen M, Schlünz M, Klingel K, Loffing J et al. 2002 Impaired renal $\mathrm{Na}(+)$ retention in the sgk1knockout mouse. Journal of Clinical Investigation 110 1263-1268.

Zecevic M, Heitzmann D, Camargo SM \& Verrey F 2004 SGK1 increases $\mathrm{Na}, \mathrm{K}-\mathrm{ATP}$ cell-surface expression and function in Xenopus laevis oocytes. Pflugers Archiv: European Journal of Physiology 448 29-35.

Zhou R \& Snyder PM 2005 Nedd4-2 phosphorylation induces serum and glucocorticoid-regulated kinase (SGK) ubiquitination and degradation. Journal of Biological Chemistry 280 4518-4523.

Received in final form 23 July 2008

Accepted 24 July 2008

Made available online as an Accepted Preprint 24 July 2008 